\title{
Pseudoleucite from the Gardar of South Greenland
}

\author{
STEPHEN P. HESSELBO
}

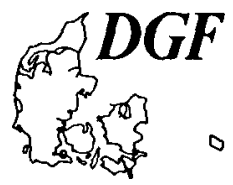

\begin{abstract}
Hesselbo, S. P. Pseudoleucite from the Gardar of South Greenland. Bull. geol. Soc. Denmark, vol. 35, pp. 11-17, Copenhagen, October, 29th, 1986. https://doi.org/10.37570/bgsd-1986-35-02

Igneous pseudoleucite has been found for the first time in the Gardar alkaline province of South Greenland. The $10 \mathrm{~cm}$ diameter pseudoleucites occur in a trachyte dyke and are comprised of radiating intergrowths of K-feldspar with sericite and cancrinite. The textures are interpretedas being a direct reflection of original nepheline/K-feldspar intergrowths. Major element and trace element data are presented and these show that the pseudoleucite retains the structural formula of leucite but with considerable alkali loss. Consideration of the textural relationships is very important in determining possible and impossible modes of genesis although in this case interpretation is constrained by the very advanced state of alteration of the rock. It is proposed that the Gardar pseudoleucites formed by a breakdown reaction of an originally sodic leucite by reaction involving deuteric waters.
\end{abstract}

University of Aberdeen, Department of Geology and Mineralogy, Marischal College, Aberdeen AB9 1AS, Scotland. (Present address: University of Bristol, Department of Geology, Wills Memorial building, Queen's Road, Bristol BS8 1RJ. England). April 26th, 1985.

\section{Introduction}

Pseudoleucites are intergrowths of two or more minerals: leucite, nepheline and K-feldspar; nepheline and feldspar; or analcite, nepheline and feldspar; or alteration products of these, thought to be pseudomorphing leucite in igneous rocks. In this paper the petrography of a new occurrence of pseudoleucite is described and interpreted within the context of current ideas concerning the genesis of pseudoleucite.

Following the initial discovery of pseudomorphs after leucite (Hussak 1890; Derby 1891; Knight 1906) debate centered around whether they originated by reaction of primary crystalline leucite with the magma during crystallisation (Bowen 1928; Bowen \& Ellestad 1937) or through subsolidus breakdown during or after the final stages of crystallisation (Knight 1906; Larsen \& Buie 1938). The most important recent work has been experimental in its approach. Fudali (1963) produced the first experimental evidence to support Knight's (1906) speculation that most pseudoleucite formed by the subsolidus breakdown of primary igneous leucite, and Taylor \& MacKenzie (1975) have shown experimentally that sodium may be transported in the vapour phase to either enrich or deplete the original leucite composition. An alternative isochemical mechanism of pseudoleucite breakdown has been suggested, especially for the most sodic examples, by Roux \& MacKenzie (1978) following further experimental work. In an extension of Fudali's work in the subsolidus system $\mathrm{NaAl}$ $\mathrm{Si}_{2} \mathrm{O}_{6}-\mathrm{KAlSi}_{2} \mathrm{O}_{6}$ at higher temperatures Edgar $(1978 ; 1980)$ found that analcite could theoretically form with feldspar and nepheline from leucite precipitated directly from liquid at higher temperatures, or even directly from the liquid without the involvement of leucite at all. Obviously there should be strong textural evidence for pseudoleucites formed in this way.

However, despite the experimental elucidation of the different processes involved in pseudoleucite formation we still have no idea of the relative frequency or importance of these processes in nature. The problem is not helped by the lack of proper descriptions of pseudoleucite intergrowth textures: although contributing greatly to many aspects of the problems of pseudoleucite genesis most of the more recent reports of pseudoleucites (Tempeleman-Kluit 1968; Watkinson 1973; Reyes 1977; Valenca \& Edgar 1979; Pivec \& Ulrych 1982) have rarely included more than a rudimentary description. Photomicrographs of unaltered intergrowths of nepheline and K-feldspar illustrated by Fudali $(1963$, p1102) are the only clear ones published and these appear to be very similar to those illustrated here although Fudali neither indicated how the textures were distri- 


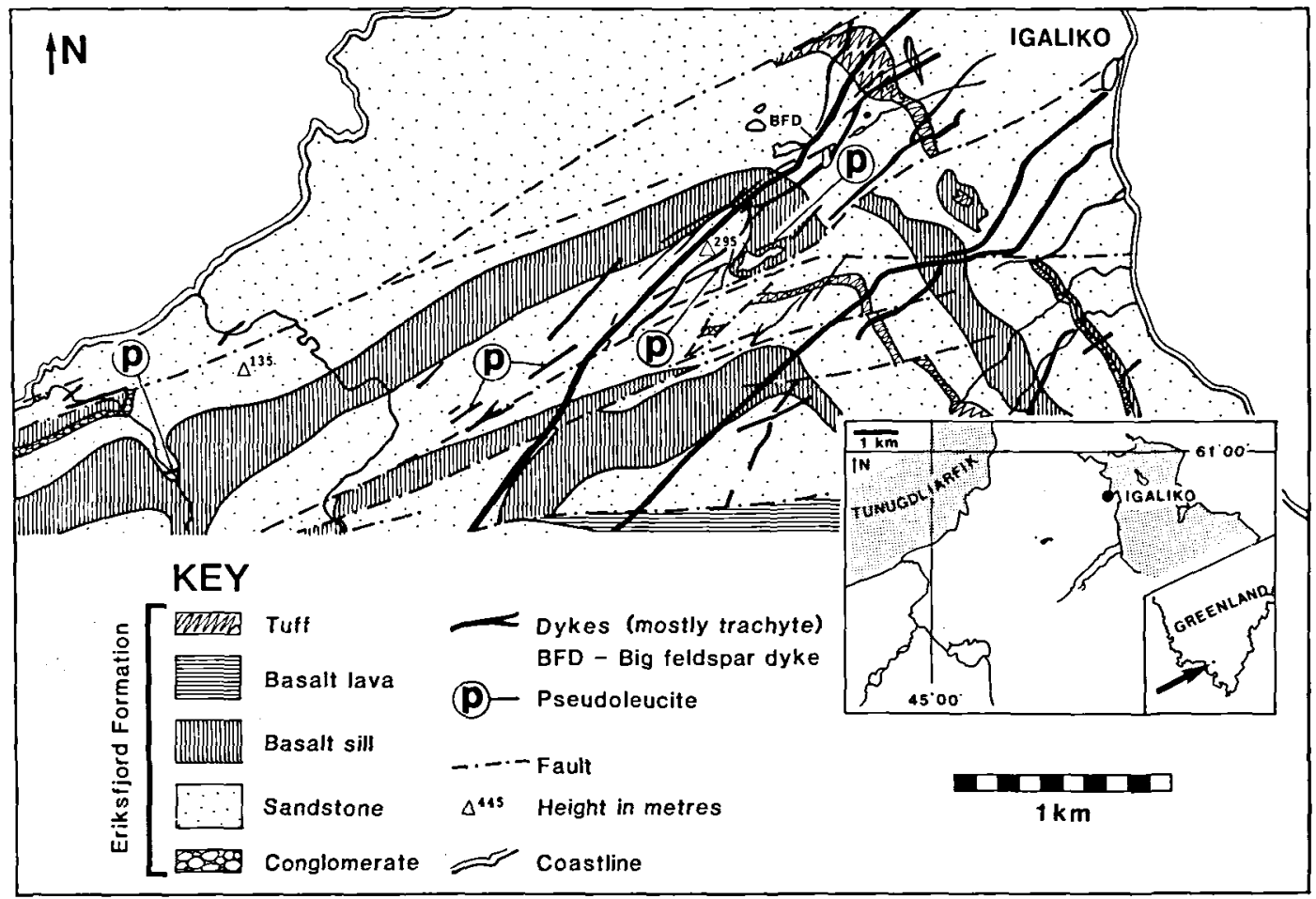

Figure 1. Localities of Gardar Pseudoleucite. Geology of western half based on mapping by the author; geology of eastern half based on published maps and additional work by Adrian Harvey. Inset shows position of area relative to the rest of south Greenland.

buted within individual pseudoleucites nor any variation between occurrences. Unfortunately genetic interpretation of the textures and mineralogy in the present example is constrained by the very high degree of alteration that the rock has undergone.

The new pseudoleucites are from a single dyke of Gardar age, that is $1330-1150 \mathrm{Ma}$ (Emeleus \& Upton 1976), intruded into Precambrian quartzites of the Eriksfjord formation west of Igaliko in South Greenland (Fig. 1). The dyke is one of a suite of alkali-intermediate dykes introduced late during the development of the generally overwhelmingly persodic Gardar igneous province (Allaart 1969). A second similar dyke swarm occurs in the Grønnedal-Ika area (Berthelsen \& Noe-Nygaard 1965; Gill 1972). Emeleus \& Upton (1976) note that these intermediate and salic rocks are younger than the four earlier complexes of the Igaliko group, but predate both the Ilimaussaq intrusion and the late Igdlerfigssalik member of the Igaliko complex. The dyke swarms from the Grønnedal-Ika area (Gill, 1972) and from Tugtutôq (Macdonald 1969) have been studied in detail and in both cases it was demonstrated that much of the variation could be explained in terms of alkali feldspar fractionation; in the pseudoleucite bearing dykes leucite fractionation must have had an important effect on the dyke composition.

\section{Description of occurrence}

\section{Introduction}

The pseudoleucites (Fig. 2) occur in a dyke of at least $2 \mathrm{~km}$ length with an average width of about $3 \mathrm{~m}$, and apart from the presence of pseudoleucite the dyke appears in the field to be identical to the most common alkali-intemediate dykes of this area which can be described as porphyritic trachyte. CIPW norms calculated from the major element data presented in table 1 characterise the rock as a potassic trachyte, a more precise desig- 


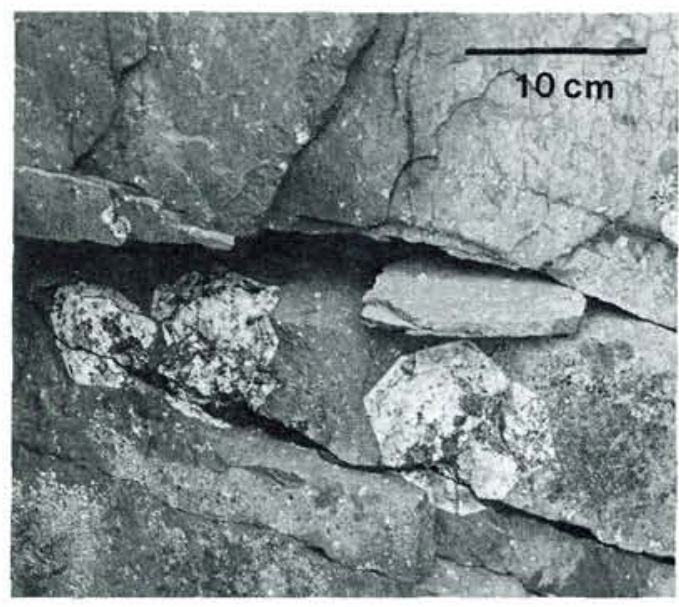

Figure 2. Appearance of pseudoleucites in outcrop.

nation than this based on modal mineralogy cannot be given because of the pervasive alteration with most of the constituent feldspars being altered to sericite and other interstitial grains altered to cancrinite/sericite (gieseckite). It is pertinent to note here that Gill (1972) recorded these minerals as replacing nepheline in similar dykes in the Gardar province and it would be fair to interpret them as replacing nepheline in the pseudoleucite too for reasons that will become apparent. After accounting for K-feldspar and muscovite in XRD analyses significant peaks with $2 \theta$ values of $13.6^{\circ}, 24.35^{\circ}, 27.75^{\circ}$ and $41.8^{\circ}$ remain unassigned. JDPS file data indicates that these could represent the Na-rich cancrinite major peaks 110,300 and 211 respectively although cancrinite shows great variation in diffraction patterns with slight compositional change. An important peak at about $18^{\circ}$ representing the 101 plane is completely absent. There is no data for the diffraction pattern of the K-rich cancrinite end-member but given the potential variability an interpretation of this mineral as K-rich cancrinite seems best with the limited information.

\section{Petrology of the Dyke}

The pseudoleucites, which usually attain a diameter of more than $10 \mathrm{~cm}$, have an icositetrahedral form and the faces are very well developed except at the crystal edges in some specimens where irregular lamellae of dyke rock have been incorporated during crystal growth. Blobs of this in- cluded material can be distinguished in Fig. 3 and have a zonal configuration especially towards the margin of the pseudoleucite.

Within the host trachyte other phenocryst phases occur. Alkali feldspar is present as large tabular euhedral phenocrysts randomly orientated within the dyke. Thin sections show these to be perthitic and highly sericitised. Large prismatic light green crystals with an apparently right-angled cleavage in basal section have been completely replaced by sericite which XRD analysis indicates as muscovite and minor chlorite and although completely replaced the remenant cleavage and characteristic sections suggest a pyroxene precursor. Elongate black phenocrysts are also common but have been completely replaced by chlorite and an amorphous opaque phase: These crystals are interpreted as amphibole pseudomorphs. Small unaltered acicular euhedral apatite crystals are present.

In addition to occurring alone all the above phenocryst phases have been incorporated within the pseudoleucite where they are concentrated relative to the matrix as glomeroporphyritic aggregates. Most phenocrysts within the pseudoleucite retain an envelope of trachyte around them (Fig. 3).

The groundmass comprises three main phases: Sericitised interpenetrating acicular K-feldspar bundles with an average length of $150-200 \mu$ and interstitial fine-grained sericite/cancrinite occur in equal abundance with lesser amounts of an anhedral opaque phase. The feldspars are randomly orientated except in a thin band $2 \mathrm{~mm}$ out from the pseudoleucite face in one thin section where they appear to be aligned with long axes parallel to the crystal faces. Phenocrysts included within the groundmass are no different in size from those present in the pseudoleucite and the leucite must, therefore, have grown more rapidly, or after, these associated minerals.

\section{Intergrowth textures}

Intergrowth textures within the pseudoleucite comprise many radiating intergrowth sets of Kfeldspar with sericite and cancrinite, the latter two minerals presumably replacing nepheline. Radiating intergrowth sets occur in at least three distinct settings: Radiation in from the pseudoleucite faces, radiation away from included phe- 

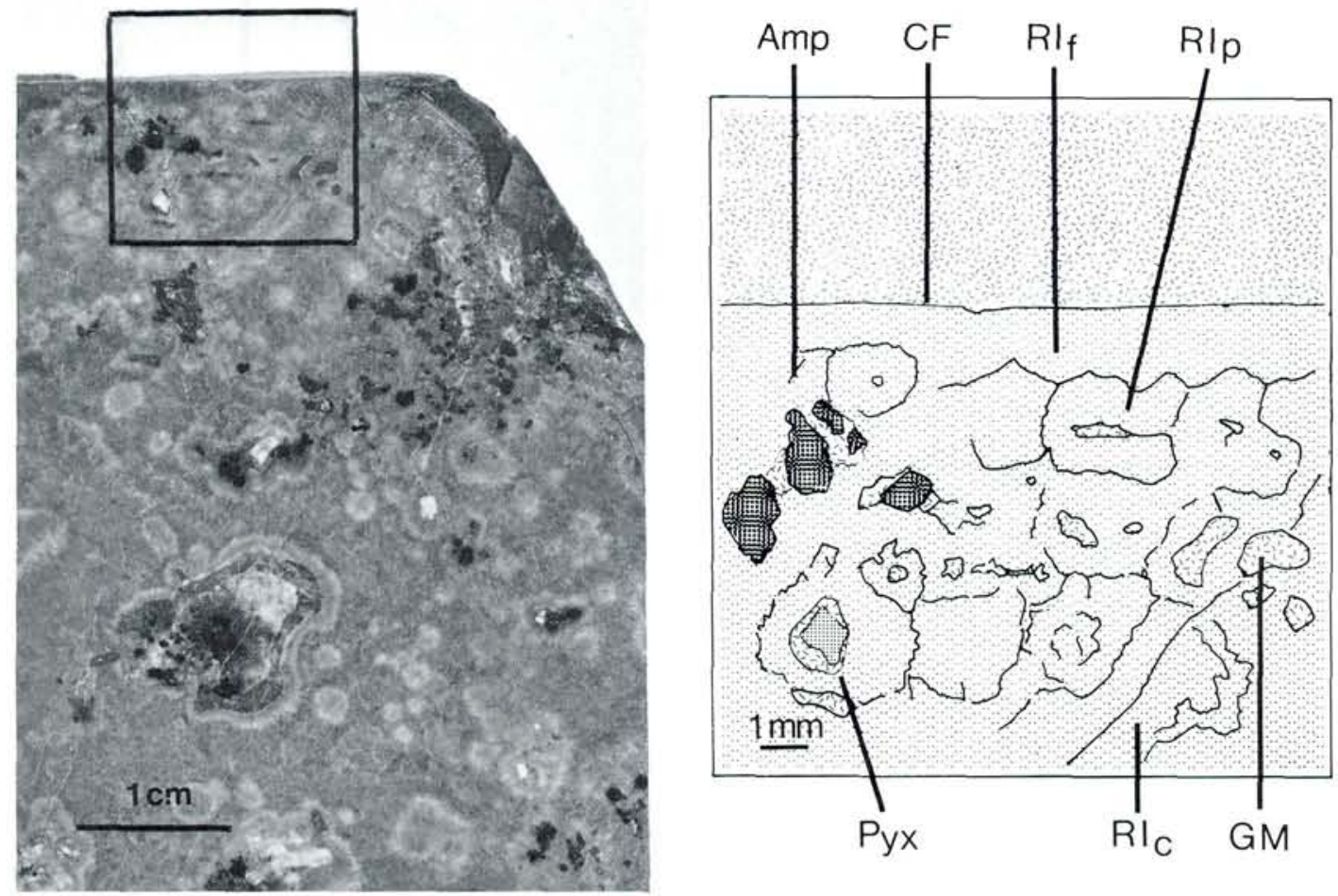

Figure 3. (A) Polished cross section through pseudoleucite. (B) Camera lucida interpretation. Amp: Amphibole. CF: Crystal face. GM: Groundmass. Pyx: Pyroxene. RI(f,c,p): Radiating intergrowth sets nucleated on crystal FACES, CRACKS and included PHENOCRYSTS or groundmass respectively.
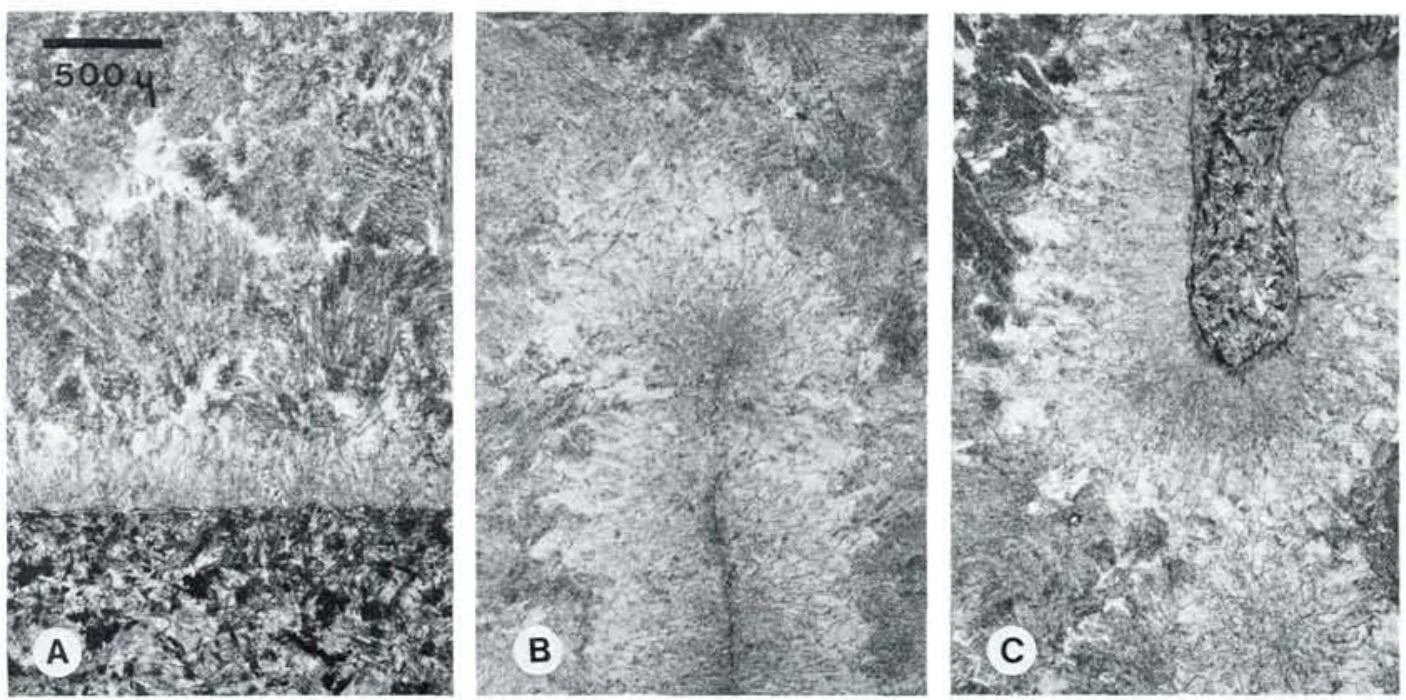

Figure 4. Relationships of the radiating intertgrowth sets to the overall crystal form; photomicrographs in plane polarised light. (A) Nucleation on crystal face. (B) Nucleation along fracture. (C) Nucleation on included phenocrysts. 


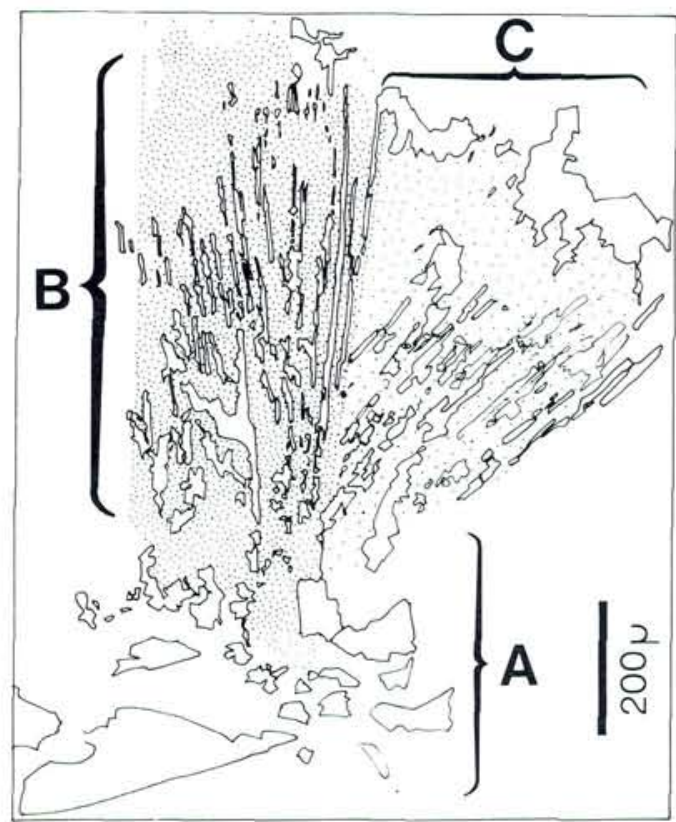

Figure 5. Camera lucida drawing from a thin section illustrating crystallographic zonation within the radiating intergrowth sets. (A) Inner zone. (B) Middle zone. (C) Outer zone. Stippled areas represent $\mathrm{K}$-feldspar grains enclosing fine-grained sericite/cancrinite.

nocrysts or matrix, and radiation away from cracks within the crystal. Fig. 4 shows these relationships clearly. Each radial intergrowth can be divided into three roughly concentric zones char- acterised by distinct crystallographic features as illustrated in Fig. 5.

An inner zone (Fig. 6A) shows a grain size gradation from submicroscopic to grains with a diameter of about $200 \mu$. Isolated grains of finely divided sericite and cancrinite are set in a matrix of K-feldspar and although irregular in shape become wider away from the centre of radiation. The $K$-feldspar is untwinned and shows roughly straight but somewhat undulose extinction.

The middle zone (Fig. 6B) is characterised by intergrowths of an entirely different nature to those of the inner zone. Finely crystalline sericite and cancrinite are present as long parallel sided stringers set within a K-feldspar grain. Within each feldspar the stringers have a distinct orientation radiating from a point approximating to the centre of the intergrowth sets. But different feldspars contain stringers with somewhat different centres of radiation within each intergrowth set. Individual feldspar grains, and hence intergrowth sets span the complete width of the zone. As with the inner zone the feldspars are untwinned and show undulose, though basically straight, extinction.

The host feldspars of the intergrowths of the middle zone (Fig. 6B) are always direct crystallographic extensions of the feldspars from the inner zone (Fig. 6A).

An outer zone of large irregular sericite/can-
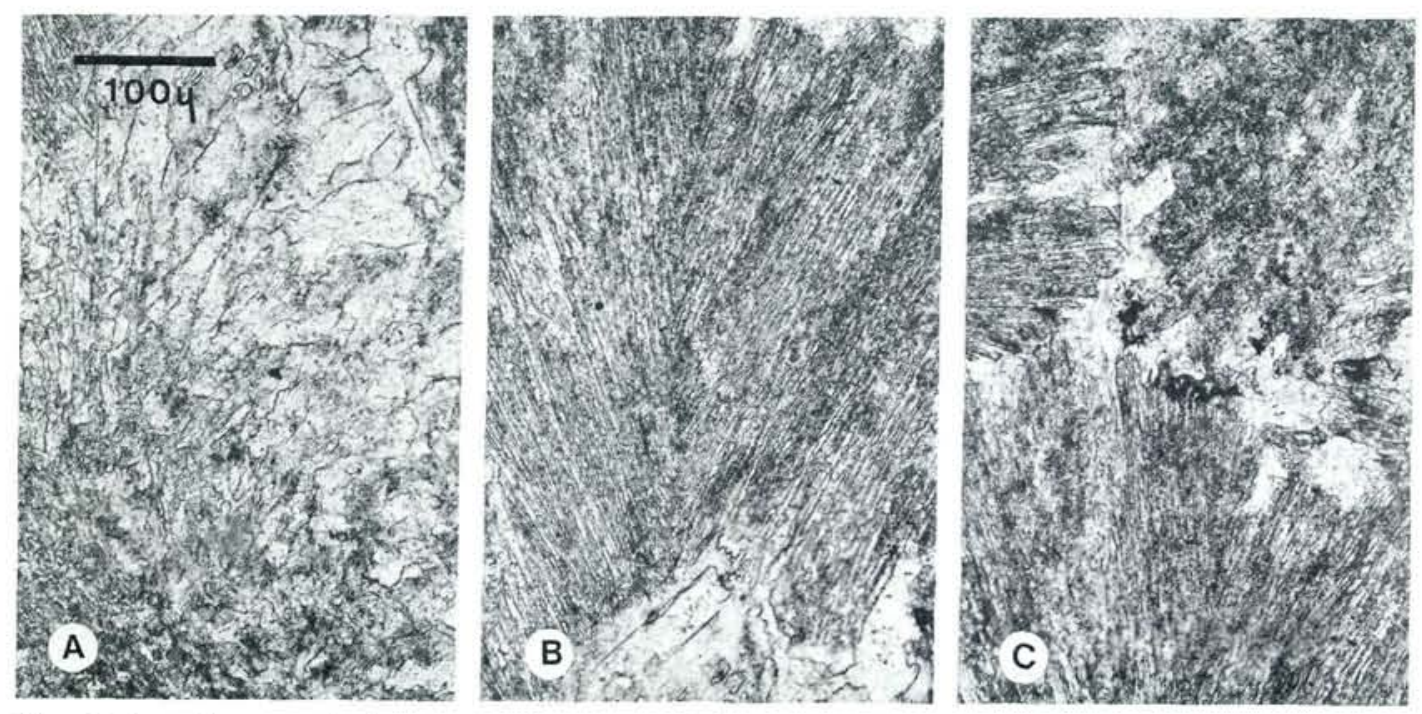

Figure 6. Photomicrographs showing zonation of crystallographic features in the intergrowths plane-polarised light. (A) Inner zone. (B) Middle zone. (C) Outer zone. See text for details. 
crinite aggregates is present around the edges of all intergrowth sets as the outer zone (Fig. 6C). These grains show no obvious relation to the crystallographic orientation of the inner zones.

\section{Chemistry of the pseudoleucites}

A wet chemical analysis of major elements and an XRF trace element analysis from the dyke groundmass and the pseudoleucite, manually separated, are presented in table 1. A microprobe analysis is presented in table 2 . The third column in table 1 shows the number of anions present in the pseudoleucite on the basis of six oxygens, the structural formula of pseudoleucite being taken as $\mathrm{K}, \mathrm{Na}\left(\mathrm{AlSi}_{2} \mathrm{O}_{6}\right)$. It can be seen that although the $\mathrm{Si} / \mathrm{Al} / \mathrm{O}$ ratios have remained true to the presumed parental leucite the alkalis are depleted by about one third of the probable initial value, thus although the leucite is now twice as potassic as sodic, the original ratios, on an atomic basis, may have been considerably different. Nevertheless the initial mineral can be interpreted with some certainty as a sodic leucite rather than a potassic analcite since even if all the now vacant alkali sites were filled with sodium, the $\mathrm{Na} / \mathrm{K}$ ratio would be only slightly greater than unity.

\section{Interpretation}

Intergrowth sets radiate away from crystal faces, fractures and phenocrysts included within the pseudoleucite and these are all surfaces and areas where pervasive fluids could be in contact with the leucite on quenching or after complete crystallisation of the groudmass. Fudali (1963) emphasized the role of water in determining the possible extent of solid solution of sodium in leucite and so it is reasonable to speculate that it was late stage water that catalysed the breakdown reaction. The radiating intergrowth sets must have formed after the leucite had stopped growing and by implication during or after crystallisation of the matrix since the intergrowth sets are distributed radiating in from all crystal faces. However the observations made here do not allow a more precise definition of the timing of the breakdown reaction.
Table 1. Wet major element analysis.

\begin{tabular}{|c|c|c|c|c|}
\hline \multirow{2}{*}{$\begin{array}{l}\text { Oxide } \\
\mathrm{SiO} 2\end{array}$} & \multirow{2}{*}{$\begin{array}{c}\begin{array}{c}\text { Ground- } \\
\text { mass } \\
\mathrm{Wt} \%\end{array} \\
56.36\end{array}$} & \multirow{2}{*}{$\begin{array}{c}\begin{array}{c}\text { Pseudoleu- } \\
\text { cite } \\
\text { Wt } \%\end{array} \\
57.63\end{array}$} & \multicolumn{2}{|c|}{ Atoms per 6 oxygens } \\
\hline & & & 1.993 & \\
\hline $\mathrm{TiO} 2$ & 0.38 & 0.31 & 0.016 & \multirow{7}{*}{1.019} \\
\hline $\mathrm{A} 12 \mathrm{O} 3$ & 21.02 & 21.82 & 0.890 & \\
\hline $\mathrm{Fe} 2 \mathrm{O} 3$ & 4.11 & 1.58 & 0.041 & \\
\hline $\mathrm{FeO}$ & 1.30 & 0.63 & 0.018 & \\
\hline $\mathrm{MnO}$ & 0.21 & 0.13 & 0.004 & \\
\hline $\mathrm{MgO}$ & 0.37 & 0.34 & 0.017 & \\
\hline $\mathrm{CaO}$ & 0.82 & 0.90 & 0.033 & \\
\hline $\mathrm{Na} 2 \mathrm{O}$ & 4.37 & 3.29 & 0.220 & \multirow{5}{*}{0.662} \\
\hline $\mathrm{K} 2 \mathrm{O}$ & 7.96 & 10.00 & 0.442 & \\
\hline $\mathrm{P} 2 \mathrm{O} 5$ & 0.11 & 0.12 & 0.003 & \\
\hline $\mathrm{CO} 2$ & 1.02 & 0.85 & 0.004 & \\
\hline $\mathrm{H} 2 \mathrm{O}$ & 1.04 & 0.94 & 0.216 & \\
\hline
\end{tabular}

Total 98.55

Trace element analysis in ppm (XRF)

$\begin{array}{lrrrrrrr} & \mathrm{Rb} & \mathrm{Ni} & \mathrm{Sr} & \mathrm{Zn} & \mathrm{Nb} & \mathrm{Zr} & \mathrm{Y} \\ \text { Pseudoleucite } & 552 & 26 & 130 & 70 & 38 & 66 & - \\ \text { Groundmass } & 194 & 19 & 115 & 127 & 247 & 925 & 39\end{array}$

CIPW normative values for the grondmass

0.25 AP, $0.72 \mathrm{IL}, 47.04$ OR, 36.98 AB, 5.22 C, 3.78 MT, 1.51 HM, 0.66 HYEN, 0.18 OLFO, 2.32 CC; OR/PLAG 55.99/ 44.01; TOT F'SPAR 84.02 .

Table 2. Wave dispersive microprobe analysis (atoms per 6 oxygens).

\begin{tabular}{lccc}
\hline Element & traverse 1 & traverse 2 & traverse 3 \\
\hline $\mathrm{Na}$ & 0.084 & 0.125 & 0.052 \\
$\mathrm{Al}$ & 0.875 & 0.955 & 1.023 \\
$\mathrm{Si}$ & 2.155 & 2.076 & 2.028 \\
$\mathrm{~K}$ & 0.625 & 0.659 & 0.704 \\
$\mathrm{Ca}$ & 0.001 & 0.000 & 0.003 \\
$\mathrm{Fe}$ & 0.020 & 0.021 & 0.026 \\
\hline
\end{tabular}

Traverses 1 and 2 across two intergrowth sets, 3 across inner zone only. ${ }^{*} \mathrm{Fe}$ calculated above at valency 2 .

\section{Conclusions}

Pseudoleucite is a major constituent of a potassic trachyte dyke of Gardar age in South Greenland. The nepheline component of the nepheline/Kfeldspar intergrowth has been altered to cancrinite and sericite but by comparison with previously published intergrowths the original reaction textures appear to have been retained. Inter- 
growths occur as sets radiating in from crystal margins, away from included phenocrysts and away from fractures within the pseudoleucite. Each radiating intergrowth set can be divided into three distinct and roughly concentric zones. The textures indicate that a subsolidus reaction took place during or after crystallisation of the dyke matrix probably in response to increasing fluid pressure.

Acknowledgements. I would particularly like to thank Prof. Ian Parsons who offered advice and enthusiasm through all stages of this work and Dr. Alan Mann who incisively critisised the first draft. Stephen Harrison led the 1982 Aberdeen University Greenland Expedition and Derek Armshaw and Adrian Harvey were fellow members of that expedition. Financial support was given by BNOC, Christian Salvesen, The Albert Reckitt Charitable Trust, The Mining Journal, Clydesdale Bank and Aberdeen University Exploration Society. I thank Shiela Whyte (University of Aberdeen) who produced the analyses, and Tom Easter (University of London Goldsmiths' College) for his excellent photographic work.

\section{Dansk sammendrag}

For første gang er der fundet intrusiv pseudoleucit i den alkaline Gardar provins i Sydgrønland. De op til $10 \mathrm{~cm}$ store pseudoleucitter forekommer i en trachyttisk gang og er opbygget af radierende sammenvoksninger af kalium feldspat sammen med sericit og cancrinit. Strukturen tolkes som værende en direkte afspejling af en oprindelig nefelin/kalium feldspat sammenvoksning. Værdier for hoved - og spor elementer viser at pseudoleucitten har bibeholdt sin structurelle formel men med et betydeligt tab af alkalier. Overvejelser over de strukturelle relationer er meget vanskelige idet bjergarten har gennemgået betydelige forandringer. Det foreslås, at Gardar pseudoleucitterne blev dannet ved en reaktion hvorved en oprindelig natrium leucit blev nedbrudt under medvirken af vand.

\section{References}

Allaart, J. H. 1969: The chronology and petrography of the Gardar dykes between Igaliko Fjord and Redekammen, South Greenland. Rapp. Gronlands geol. Unders. 25: $26 \mathrm{pp}$.
Berthelsen, A. \& Noe-Nygaard, A. 1965: The Precambrian of Greenland. In Rankama, K. (ed.) The geologic systems. The Precambrian. Volume 2. Interscience Publishers: New York, pp 113-262.

Bowen, N. L. 1928: The evolution of the igneous rocks. Princeton University Press: Princeton, NJ.

Bowen, N. L. and Ellestad, R. B. 1937: Leucite and Pseudoleucite. Am. Mineral. 22: 409-415.

Derby, O. A. 1891: On nepheline rocks in Brazil. Part 2. The Tingua Mass. Quart. J. geol. Soc. 47: 251-265.

Edgar, A. D. 1978: Subsolidus phase relations in the system NaAISi2O6-KAlSi2O6 at $1 \mathrm{~kb} \mathrm{Ph} 2 \mathrm{O}$ and their bearing on the origin of pseudoleucites and analcime in igneous rocks. N. Jb. Miner. Mh. H.5: 210-222.

Edgar, A. D. 1980: Subsolidus phase relations in the system NaAlSi2O6-KAISi2O6 at $1 \mathrm{~kb} \mathrm{PH} 2 \mathrm{O}$ and their bearing on the origin of pseudoleucites and analcime in igneous rocks: corrigenda. N. Jb. Miner. Mh. H.3: 138-139.

Emeleus, C. H. \& Upton, B. G. J. 1976: The Gardar period in southern Greenland. In Escher, A. and Watt, W. S. (eds.): Geology of Greenland. Gronlands Geologiske undersøgelse: Denmark, pp 153-181.

Fudali, R. F. 1963: Experimental studies bearing on the origin of pseudoleucite and associated problems of alkalic rock systems. Bull. geol. Soc. Am. 74: 1101-1126.

Gill, R. C. O. 1972: Chemistry of peralkaline phonolite dykes from the Gronnedal-Ika area, South Greenland. Contrib. Mineral. Petrol. 34: 87-100.

Hussak, E. 1890: Ueber leucit-pseudokrystalle in phonolith (tingauait) der Serra de Tingua, estado Rio de Janeiro, Brazil. Neues Jahrb. 1: 166-169.

Knight, C. W. 1906: A new occurrence of pseudo-leucite. Am. J. Sci. 21: 286-293.

Larsen, E. S. \& Buie, B. F. 1938: Potash analcite and pseudoleucite from the Highwood Mountains of Montana. Am. Mineral. 23: 837-849.

Macdonald, R. 1969: The petrology of the alkaline dykes from the Tugtutoq area, South Greenland. Bull. geol. Soc. Denmark 19: 257-286.

Pivec, E. \& Ulrych, J. 1982: Pseudoleucite from Loucna (Oberwiesenthal), Krusne Hory Mountains (Erzgebirge), Czechoslovakia. $N$. Jb. Miner. Mh. H.5: 227-236.

Reyes, R. A. 1977: Pseudoleucites of Cordon, Isabela, J. Geol. Soc Phillip 31: 38-56.

Roux, J. \& MacKenzie, W. S. 1978: Sodium in leucite and its petrogenetic significance: an experimental study. Bull. Mineral. 101: 478-484.

Taylor, D. \& MacKenzie, W. S. 1975: A contribution to the pseudoleucite problem. contrib. Mineral. Petrol. 49: 321333.

Tempelman-Kluit, D. K. 1968: A re-examination of pseudoleucite from the Spotted Fawn Creek, west-central Yukon. Can. J. Earth Sci. 6: 55-62.

Valenca, J. G. \& Edgar, A. D. 1979: Pseudoleucites from Rio de Janeiro State, Brazil. Am. Mineral. 64: 733-735.

Watkinson, D. H. 1973: Pseudoleucite from alkalic rock-carbonatite complexes. Can. Mineral. 12: 129-134. 